\title{
Harvesting of Protium heptaphyllum (Aubl.) March. seeds (Burseraceae) by the leaf-cutting ant Atta sexdens L. promotes seed aggregation and seedling mortality
}

\author{
PAULO D. SILVA ${ }^{1}$, INARA R. LEAL ${ }^{1}$, RAINER WIRTH ${ }^{2}$ and MARCELO TABARELLI ${ }^{1,3}$
}

(received: January 01, 2006; accepted: September 28, 2007)

\begin{abstract}
Harvesting of Protium heptaphyllum (Aubl.) March. seeds (Burseraceae) by the leaf-cutting ant Atta sexdens L. promotes seed aggregation and seedling mortality). The role played by leaf-cutting ants as seed dispersers of nonmyrmecochorous plants remains poorly understood. Here we document the harvesting of Protium heptaphyllum (Aubl.) March. seeds (Burseraceae) by the leaf-cutting ant Atta sexdens L. and its consequences for (1) seed deposition pattern; (2) seed germination; and (3) seedling mortality. The study was carried out at Dois Irmãos, a 390 ha reserve of Atlantic forest, northeast Brazil. Ant-seed harvesting on the ground was detected in $18.5 \%$ of all fruiting trees and ants harvested $41.1 \% \pm$ $19.7 \%$ of the seed crop (mean $\pm s$ ). In average, ants piled seeds $3.4 \pm 2.2 \mathrm{~m}$ away from the trunk of parent trees and seed density in these piles reached $128.8 \pm 138.8$ seeds $0.25 \mathrm{~m}^{2}$ during the peak of seed discarding by ants. During a 13 month period, mean seedling mortality varied from $0.54 \%$ up to $10.6 \%$ in ant-made seed piles $v s .0 .05-4.2 \%$ in control samples, what resulted in a total seedling mortality of $97.7 \% \mathrm{vs.} 81 \%$. Ants systematically cut seedling epicotyls, accounting for $55 \%$ of seedling mortality in seed piles, whereas only 14 seedlings $(4.2 \%)$ were cut by ants in the control samples. Our results suggest that seed harvesting by A. sexdens (1) affects approximately $20 \%$ of fruiting P. heptaphyllum trees and their seed crops; (2) promotes short-distance seed dispersal and high levels of seed aggregation; and (3) reduces seedling survival beneath parents.
\end{abstract}

Key words - Atlantic forest, Atta sexdens, leaf-cutting ants, Protium heptaphyllum, seed dispersal

RESUMO - (Coleta de sementes de Protium heptaphyllum (Aubl.) March. (Burseraceae) pela formiga cortadeira Atta sexdens L. promove agregação de sementes e mortalidade de plântulas). O papel das formigas cortadeiras como dispersoras de sementes de plantas não-mirmecocóricas permanece pouco conhecido. Neste artigo nós documentamos a remoção de sementes de Protium heptaphyllum (Aubl.) March. (Burseraceae) pela formiga cortadeira Atta sexdens L. e suas conseqüências em termos de (1) padrão de deposição de sementes; (2) germinação; e (3) mortalidade de plântulas. O estudo foi desenvolvido em Dois Irmãos, uma reserva de 390 ha de Floresta Atlântica no Nordeste do Brasil. As formigas coletaram 41,1\% $\pm 19,7 \%$ (média $\pm s$ ) da produção total de sementes e a remoção foi verificada em 18,5\% de todas as árvores que frutificaram. Em média, as formigas amontoaram sementes a 3,4 $\pm 2,2 \mathrm{~m}$ de distância dos troncos das plantas-mãe e a densidade de sementes nas pilhas alcançou $128,8 \pm 138,8$ sementes $0,25 \mathrm{~m}^{2}$ durante o pico de descarte pelas formigas. Durante o período de 13 meses, a mortalidade média das plântulas variou entre $0,54 \%$ até $10,6 \%$ nas pilhas formadas pelas formigas $v s .0,05 \%-4,2 \%$ nas amostras controles, o que resultou numa mortalidade total de $97,7 \%$ vs. $81 \%$ respectivamente. As formigas cortaram sistematicamente o epicótilo das plântulas, respondendo por 55\% da mortalidade nas pilhas. Em comparação, nas amostras controles, somente 14 plântulas $(4,2 \%)$ foram cortadas pelas formigas. Nossos resultados indicam que a coleta de sementes por A. sexdens (1) pode afetar aproximadamente $20 \%$ das árvores reprodutivas e suas respectivas produções de sementes; (2) promove dispersão à curta distância e altos níveis de agregação das sementes; e (3) reduz a sobrevivência das plântulas debaixo das plantas-mãe.

Palavras-chave - Atta sexdens, dispersão de sementes, floresta Atlântica, formigas cortadeiras, Protium heptaphyllum

\section{Introduction}

Seed dispersal and seedling establishment represent the most critical and sensitive stages in the life history of plants (Terborgh 1990). Benefits of seed dispersal usually include reduced levels of seed predation, improvement

\footnotetext{
1. Universidade Federal de Pernambuco, Departamento de Botânica, 50670-901 Recife, PE, Brasil.

2. University of Kaiserslautern, Department of Plant Ecology \& Systematics, Postfach 3049, 67653 Kaiserslautern, Germany.

3._Corresponding author: mtrelli@ufpe.br
}

of seed germination, and colonization of new habitats (Howe \& Smallwood 1982). In the case of neotropical forests and savannas, vertebrate-seed dispersal is one of the most important mechanism of propagule dissemination among trees (Peres \& Roosmalen 2002, Ribeiro \& Tabarelli 2002). Seeds of tree species are usually dispersed through gut-dispersal by primates, birds, and ungulates; through scatter hoarding by rodents, such as agoutis, pacas and spiny rats; or through a combination of both modes (Howe 1990, Spironello 1999, Turner 2001).

Tree and shrub seed dispersal in these ecosystems may also include secondary seed dispersal by fungus- 
growing ants of the tribe Attini. These ants, including the leaf-cutting ant (LCA) genera Atta and Acromyrmex, have a synzoochorous dispersal mode, as they commonly collect fruits and seeds on the forest floor or directly on trees to supply substrate for their fungus gardens (Leal \& Oliveira 1998, Varela \& Perera 2003, Wirth et al. 2003). The proportion of non-foliar plant material (including fruits, seeds, flower parts, etc.) of the total biomass intake of LCAs can be considerable, ranging from 5\% to $25 \%$ (Shepherd 1985, Wirth et al. 2003 respectively for Atta colombica) up to $95 \%$ (Wetterer 1991 for Acromyrmex octospinosus) depending on plant phenology, colony location and ant species. To give an example, Dalling and Wirth (1998) estimated that a single colony of A. colombica harvested 136,200 fruits of Miconia argentea (a small pioneer tree) during a 49 day period in Barro Colorado Island, Panama.

Briefly, seed manipulation by LCAs include seed carrying to the subterranean ant nests and deposition of the mostly viable seeds on refuse dumps outside of the nest, after the fleshy material covering the seeds has been exhausted by fungi or eaten by ants. During fruit/ seed harvesting, several seeds may be lost along ant trails and others can be abandoned in the vicinity of nest entrances after the ants eat or remove seed fleshy contents (i.e., fruit parts adhered to the seeds or arils, Leal \& Oliveira 1998). Farji-Brener \& Silva (1996) showed that seed-cleaning activity of Atta laevigata on seeds of Tapirira velutinifolia increased seed germination rate in a parkland savanna in Venezuela. In addition, these ants frequently abandon several seeds on nutrient-rich sites, which offer better conditions for Tapirira seedling growth. On the other hand, Atta sexdens and other LCAs have been described as seed predators rather than seed dispersers for certain tropical trees. For instance, seeds either serve as substrate for the symbiotic fungi, or seeds are disposed deep inside ant nests where germination and seedling survival are unlikely (Nepstad et al. 1990, Moutinho et al. 1993, Nascimento \& Proctor 1996, Leal \& Oliveira 1998, Moutinho et al. 2003). Moreover, seed aggregating on the nest surface or on refuse piles (FarjiBrener \& Medina 2000, Varela \& Perera 2003) is likely to enhance seedling intraspecific competition, herbivory and/or pathogen attack, thus increasing seedling mortality (Wirth et al. 2003). These findings also suggest that seed harvesting by LCAs may simultaneously provide both negative and positive seed dispersal services.

In fact, LCAs appear be able to remove significant quantities and drastically alter seed spatial distribution of several primarily vertebrate-dispersed (i.e., nonmyrmecochorous) plant species. However, the whole suit of seed dispersal services provided by LCAs as well as their impacts on seedling recruitment is still poorly understood because few cases have been described in the literature (Turner 2001). Here we document the harvesting of the seeds of Protium heptaphyllum (Aubl.) March. (Burseraceae) by the leaf-cutting ant $A$. sexdens and its consequences for (1) seed deposition pattern; (2) seed germination; and (3) seedling mortality in a fragment of the Brazilian Atlantic forest. Precisely, we describe seed manipulation by ants and its magnitude in terms of tree visiting and seed crop removal. Further, we present scores of seed piling and rates of seed germination among (1) seeds piled by ants on foraging gallery entrances beneath $P$. heptaphyllum crowns (ant-made seed piles); and (2) seeds that naturally fell from P. heptaphyllum parents beneath their crowns without subsequent treatment by secondary dispersers (control samples). Finally, we address categories and rates of mortality among seedlings from these two seed sources. By the analysis of both seed and seedling fate, we discuss the role played by $A$. sexdens as seed disperser of P. heptaphyllum.

\section{Material and methods}

Study site and species - The study was conducted at the Dois Irmãos Reserve (087' S, 3452' W), a 390 ha fragment of Atlantic forest located in the State of Pernambuco, Brazil. The climate is tropical (As'of Köppen) with temperatures ranging from $23{ }^{\circ} \mathrm{C}$ to $30^{\circ} \mathrm{C}$ throughout the year. The annual rainfall is around $2,460 \mathrm{~mm}$, and a markedly dry season occurs between September and February. The wettest period covers March to August (Machado et al. 1998). Vegetation can be classified as a tropical lowland rain forest (Veloso et al. 1991). Like other portions of lowland Atlantic forest, species richness of vascular plants peaks in the Leguminosae, Lauraceae, Euphorbiaceae, Melastomataceae and Sapotaceae (Guedes 1992). Detailed information on the Dois Irmãos Reserve is available in Machado et al. (1998).

Protium heptaphyllum (Burseraceae) is a frequent canopy shade-tolerant tree in the Atlantic forest of Northeast Brazil. P. heptaphyllum produces globose reddish drupes, measuring $1.3-1.5 \mathrm{~cm} \times 0.8-1.5 \mathrm{~cm}$. The pericarp of ripe fruits split in two parts, exposing one pyrene $(0.8 \mathrm{~cm}$ in length), which is covered by a fleshy aril, $2 \mathrm{~mm}$ thick (Roosmalen 1985, Silva 2003). P. heptaphyllum species are considered to be endozoochorous because their seeds are gut-dispersed by birds (e.g., toucans, cotingas, guans), and mammals (e.g., spider and howler monkeys, kinkajous, and opossums) (Roosmalen 1985, Leigh et al. 1993, Levey et al. 1994). A specimen of $P$. heptaphyllum collected in Dois Irmãos is deposited in the UFP Herbarium (voucher no $\mathbf{0}$ 7.705), Universidade Federal de Pernambuco.

Atta nests at the study site - At Dois Irmãos Reserve hundreds of pyrenes (hereafter seeds as usually referred in the literature), 
with intact arils, fall to the ground beneath the parent trees and are removed by the LCA Atta sexdens. Ants take many seeds to their gallery entrances, which are often located beneath or in the periphery of $P$. heptaphyllum trees. The subterranean galleries, a recognized feature of foraging in $A$. sexdens (Vasconcelos 1990, Fowler \& Claver 1991), represent long-term connections to the nests that are temporarily activated during times of $P$. heptaphyllum fruit fall. The length of the galleries ranged from 20 to $60 \mathrm{~m}$, depending on their exact course, and the location of the corresponding Atta nest (Silva 2003). Specimens of $A$. sexdens collected at Dois Irmãos are deposited in the insect collection of the Plant Ecology Laboratory, Universidade Federal de Pernambuco.

Inside the galleries, ants remove the aril and discard the intact seeds aboveground in the vicinity of gallery entrances ( $<0.5 \mathrm{~m}$ distant). These discarded seeds form high-density refuse piles from which seedling-clumps emerge. Both antmade seed piles and the resulting seedling clumps cover ca. $0.25 \mathrm{~m}^{2}$ in the vicinity of gallery entrances (Silva 2003). In the area where $P$. heptaphyllum trees were observed to be accessed by LCAs we found a total of three adult $A$. sexdens nests and records of $P$. heptaphyllum seed removal by other ant taxa in the study site are lacking.

Seed harvesting by ants - To describe and quantify the magnitude of $P$. heptaphyllum seed harvesting by Atta sexdens we selected 113 adult $P$. heptaphyllum trees (diameter at breast height $>10 \mathrm{~cm}$ ) by a haphazard manner and surveyed them for (1) ant gallery entrances; (2) seed harvesting by ants; and (3) ant-made seed piles during the fruiting season of 2002 (i.e., January to March). This survey was based on exhaustive random walks up to $30 \mathrm{~m}$ of distance from parents. For a more detailed examination of the spatial distribution of seed piles around P. heptaphyllum trees, we selected a subsample of 38 trees which encompassed all trees accessed by ants through galleries within our sample of 113 trees. Here we recorded all ant gallery entrances and measured their distances to the trunks of $P$. heptaphyllum trees. Simultaneously we spent a total of $30 \mathrm{~h}$ observing seed-harvesting features of $A$. sexdens.

To get an idea about the quantitative relevance of seed harvesting by LCAs, we estimated the crop size of ten fruiting $P$. heptaphyllum trees (hereafter focal trees) by (1) counting all pericarp parts recorded beneath and in the close periphery of focal trees from the beginning of fruit fall (i.e., one fruit = two pericarp parts); and (2) monitoring fruit/seed removal by arboreal vertebrates during $250 \mathrm{~h}$ of observation on focal trees. Observation was equally distributed among focal trees and it was carried out by using $10 \times 40$ binoculars. The ten focal trees were randomly selected among 13 P. heptaphyllum fruiting trees in which ants promoted seed harvesting through galleries.

Seed and seedling fate - In order to investigate the consequences of seed harvesting by A. sexdens for (1) seed deposition pattern; (2) seed germination; and (3) seedling mortality we monitored seeds and seedlings in two situations as follow. Ant-made seed piles consisting of a total of 27 seed piles located in the vicinity of ant gallery entrances beneath the crown of the mentioned ten focal trees. The number of seed piles per focal tree ranged from one to four and each seed pile resulted from ant activity via a single gallery, a fact that indicates a certain level of independence among seed piles. We selected ant-made seed piles beneath the crown of fruiting trees because both seed harvesting and discarding by ants occurred exclusively in this area. Control samples of untouched-seeds consisted of $270.25 \mathrm{~m}^{2}$ plots $(0.5 \mathrm{mx} 0.5 \mathrm{~m})$, which exclusively included seeds that naturally fell from focal trees without subsequent treatment by secondary dispersers (e.g., ants or any other animal). These plots were set $1 \mathrm{~m}$ distant from antmade seed piles (one plot each), beneath the crown of focal trees and apart of the main above-ground foraging trail leading to the gallery entrance as depicted in the figure 1. Location of control plots was defined based on previous observations (Silva 2003), which demonstrated that (1) seed harvesting is negligible around gallery entrances, particularly in the spots apart from the main above-ground foraging trail; and (2) seedling cutting by ants occurs preferentially in ant-made seed piles (i.e., high activity spots for LCAs), although few seedlings may be occasionally cut at any area beneath parent crows. We opted for $0.25 \mathrm{~m}^{2}$ plots because this area largely corresponded to the ground area covered by ant-made seed piles and the resulting seedling clumps (Silva 2003).

The experiment was set up in the beginning of February 2002 , one month after the focal trees started to produce ripe fruits and right at the time when ant-made seed piles started to appear in the vicinity of gallery entrances. We monitored all seeds and seedlings that emerged from the seed piles and from the control samples until March 2003 (i.e., during a period of 13 months). We checked both seed and seedling fate in five-day intervals by counting all of them, including the few seeds that subsequently and inevitably dropped from focal

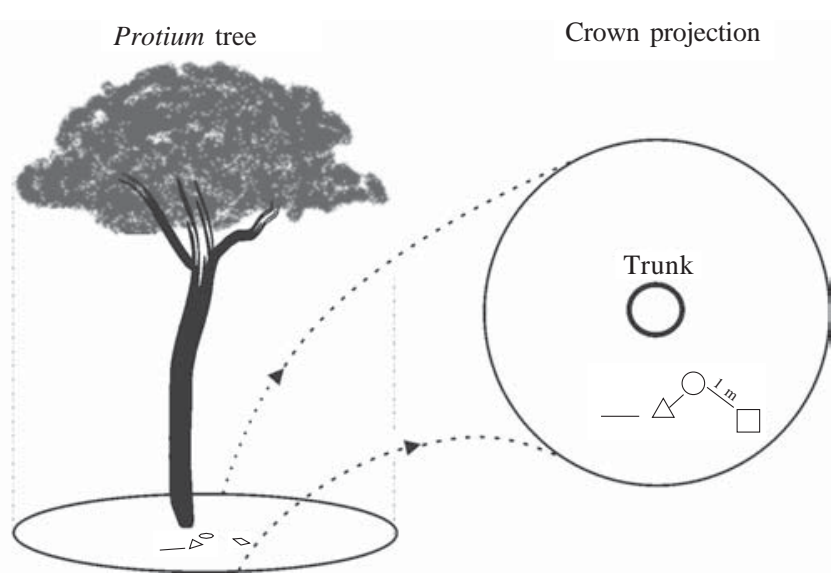

Figure 1. Schematic drawing showing the disposal of the main above-ground foraging trail leading to the gallery entrances $(-)$, ant gallery entrances $(\Delta)$, ant-made seed piles (o) and plots $(\square)$ allocated to sample untouched seeds beneath focal Protium heptaphyllum trees. 
tree crowns into plots and seed piles. This did not bias the data because all seeds that dropped into ant-made seed piles were harvested by the ants and re-disposed on the piles after aril removal inside the galleries. Seedlings that died during the monitoring period were assigned to one of three categories of mortality: (1) cutting by LCAs; (2) death in the presence of intense foliar necrosis; and (3) unknown reasons. Intense foliar necrosis symptomatically appeared in dense clusters of seedlings beneath the crowns of focal trees between March and October (with a peak in June). According to phytopathological studies conducted at the Clínica Fitosanitária de Pernambuco, and an analysis of mineral contents of the affected seedlings $(n=50)$ as compared to healthy plants, the symptoms were due to a deficiency of potassium rather than a pathogen infection (Silva 2003).

Based on these procedures we addressed the following variables in both ant-made seed piles and control samples: (1) mean density of seeds per pile and plot at the end of February 2002 , which corresponded to the peak of seed discarding and of accumulation in ant-made seed piles ( $n=27$ piles and plots); and (2) mean seedling density per pile and plot at the end of March 2002, which corresponded to the peak of recruitment ( $n=27$ piles and plots). These variables were addressed in order to describe the magnitude of seed piling by ants and the resulting seedling aggregation. Here individual piles and plots represented the replicates. We also calculated: (1) total seed germination and total seedling mortality - the percent of seed germination and seedling mortality considering all seeds and seedlings recorded during a 13 month period ( $n=3,782$ seeds and 2,986 seedlings); and (2) the relative contribution of each category of seedling mortality $(n=2,986$ seedlings). For these variables individual seeds and seedlings were the replicates as we pooled all seeds and seedlings recorded within the 27 piles and 27 plots. Finally, we calculated mean seedling mortality along the 13 month period considering the individual ant-made seed piles and plots from the control samples as replicates $(n=27)$.

Statistical analysis - Statistical comparisons were exclusive for those variables having individual ant-made seed piles and control samples as replicates (i.e., the true independent replicates, $n=27$ ). Differences in the (1) mean seed density; (2) mean seedling density; and (3) mean seedling mortality between ant-made seed piles and control samples were analyzed by Wilcoxon tests (Sokal \& Rohlf 1995), which were performed by SYSTAT 6.0 (Wilkinson 1996).

\section{Results}

Seed harvesting by ants - Among the 113 surveyed Protium heptaphyllum trees, 70 produced fruits and at 38 of them we recorded a total of 74 ant gallery entrances. Eighty five percent of theses entrances were located beneath the P. heptaphyllum crowns and $15 \%$ in the close periphery of trees. On average, these 38 trees were accessed by $2.9 \pm 2.7$ (mean $\pm s$ ) ant gallery entrances beneath their crowns. Although these 38 trees presented ant galleries, seed-harvesting activity by ants on the ground was restricted to a subset of 13 fruiting trees, i.e. $18.5 \%$ of all fruiting trees. Finally, we recorded 30 ant-made seed piles beneath the crown of these 13 trees and such piles were not found anywhere except beneath the $P$. heptaphyllum trees. In fact, the mean distance between seed-piles and the trunk of fruiting trees was $3.4 \mathrm{~m} \pm 2.2 \mathrm{~m}$.

Ants manipulated seeds in two different ways: (1) seeds covered by arils were carried to ant galleries and subsequently discarded clean on the gallery entrances, or (2) ants removed seed arils at the place where seeds were dropped and did not move them any farther. Both activities were restricted to the period of fruit fall (January 2002 to March 2002) with a peak in February. In total we recorded 13,176 pericarp parts on the ground beneath the ten focal trees. We also had six records of a group of 2-3 marmosets (Callitrix jacchus), which manipulated a total of 139 fruits in the canopies. However, we did not observe any fruit or seed taken away from the parent trees since marmosets ate the arils and dropped seeds and pericarps beneath the crowns. Frugivorous birds were not observed removing seeds from focal trees as well. Based on these observations we estimated that the ten focal trees produced a total of 6,588 fruits (811.6 \pm 700.7 fruits per tree). Ants piled at least 3,480 seeds in 27 seed piles, which corresponded to $41.1 \% \pm 19.7 \%$ of the seed crop produced by focal trees.

Seed and seedling fate - Seed density in ant-made seed piles reached $128.8 \pm 133.8$ seeds $0.25 \mathrm{~m}^{2}$ (4-446 seeds) in the peak of seed accumulation by ants in February 2002 (i.e., the maximum seed density). In contrast, control samples reached a maximum of $21.03 \pm 18.5$ seeds 0.25 $\mathrm{m}^{2}$ (1-72 seeds), a significant difference of nearly $600 \%$ in average seed density $(Z=4.2, n=27, P<0.001)$. After a 13 month period, total seed germination in seed piles $(74.1 \%)$ was similar to that in the control samples $(71.8 \%)$. Seeds that did not germinate were found rotten after the study period irrespective of their source.

During the 13 month period 2,580 seedlings emerged in the ant-made seed piles compared to 406 in the control samples. At the peak of seedling recruitment in March 2003 mean seedling density reached $95.5 \pm$ 103.6 seedlings $0.25 \mathrm{~m}^{2}$ in seed piles $v s .15 .1 \pm 15.1$ seedlings $0.25 \mathrm{~m}^{2}$ in control samples $(Z=4.3, n=27, P$ $<0.0001)$. After the 13 months, total seedling mortality reached $97.7 \%$ in seed piles vs. $81 \%$ in control samples and, during this period, ants systematically cut the epicotyls and leaves of the seedlings that emerged in seed piles, accounting for $55 \%$ of mortality among these 
seedlings. Moreover, seedling cutting by ants was almost entirely restricted to those on seed piles, and the leaf material removed was not harvested and carried into the nests. Seedling mortality in the presence of foliar necrosis was also high (43\%) in ant-made seed piles. In contrast, mortality due to foliar necrosis prevailed (91.3\%) among seedlings from control samples as only 14 seedlings (4.2\%) were cut by ants. Seedling mortality by unknown reasons played a minor role in both situations (2-4.5\% of all dead seedlings).

Mean seedling mortality by category (with respect to the total number of seedlings) was markedly seasonal in ant-made seed piles. Both leaf-cutting by ants and foliar necrosis occurred during the rainy season, with maximum values during the peak of seedling recruitment in March 2002 and approximately at the annual peak of rainfall in June, respectively (figure 2). Death by unknown reasons occurred later and almost restricted to the dry season from October $(0.16 \pm 0.05 \%)$ to March $(0.47 \pm 0.11 \%)$. Finally and furthermore, mean seedling mortality during the 13 month period differed between situations $(Z=2.7$, $n=13, P=0.006$ ), as it varied from $0.54 \%$ (with respect to the number of seedlings alive in the last count) up to $10.6 \%$ in ant-made seed piles vs. $0.05-4.2 \%$ in control samples (figure 3). In synthesis, seedlings died at faster rates and a lower number of seedlings survived in antmade seed piles as compared to the control samples.

\section{Discussion}

Leaf-cutting ants, especially Atta species, constitute a conspicuous component of neotropical forest biotas (Cherrett 1989). Among 16 Atta species, nine inhabit

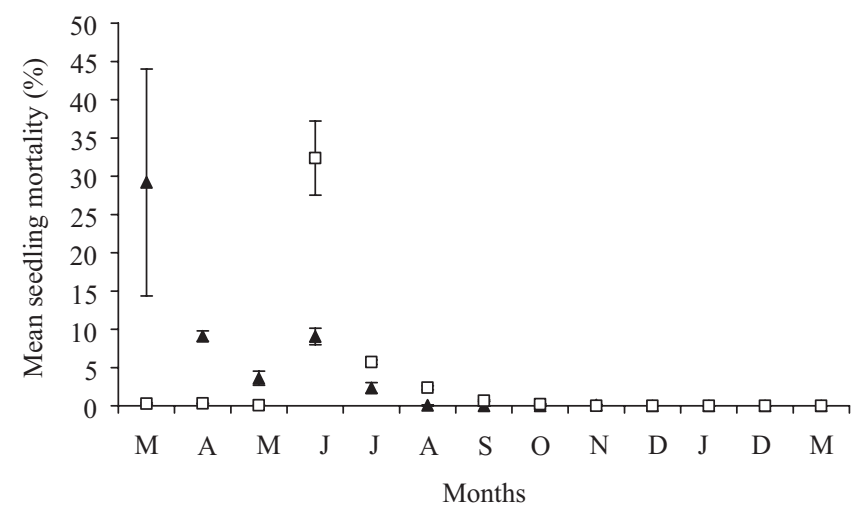

Figure 2. Mean seedling mortality $( \pm s)$ by category in antmade seed piles $(n=27)$ during a 13 month period (March 2002-March 2003) at the Reserva de Dois Irmãos, Brazil. Rainy season covers March to August and the dry season covers September to February ( $\boldsymbol{\Lambda}=$ cutting by ants; $\square=$ foliar necrosis).

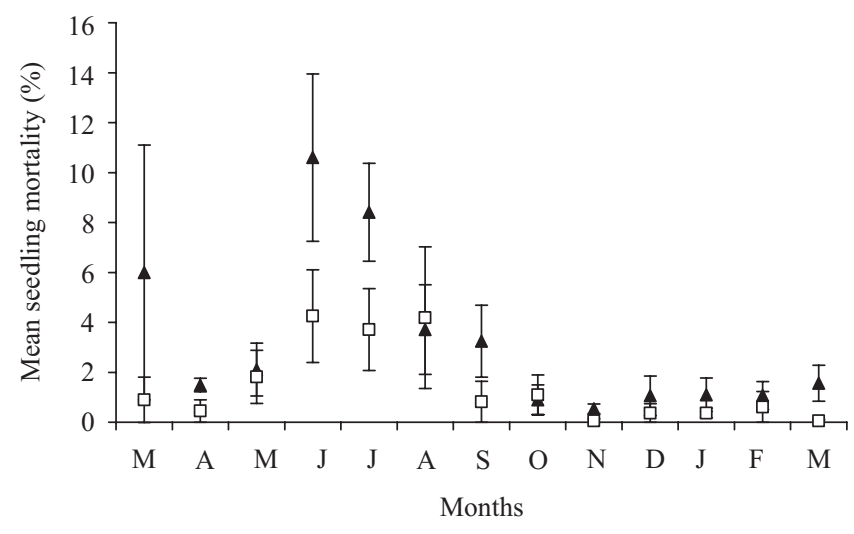

Figure 3. Mean seedling mortality $( \pm s)$ of Protium heptaphyllum seedlings in ant-made seed piles $(n=27)$, and in control samples with untouched seeds $(n=27)$ during a 13 month period (March 2002-March 2003) at the Reserva de Dois Irmãos, Brazil ( $\boldsymbol{\Lambda}=$ ant-made seed piles; $\square=$ control samples).

this ecosystem (Fowler \& Claver 1991). Fruit and seed harvesting by LCAs have been reported for dozens of tree and shrub species in neotropical forests (Nepstad et al. 1990, Dalling \& Wirth 1998, Farji-Brener \& Medina 2000, Pizo \& Oliveira 1998, Varela \& Perera 2003), most of them showing features associated with primary seed dispersal by vertebrates (e.g., arillate seeds, fleshy fruits). Despite the fact that LCAs have been well-recognized as potential seed dispersers detailed quantitative studies on the extent and plant demographic consequences of this behaviour are still scarce (Dalling \& Wirth 1998).

Our results suggest that the seed harvesting by the LCA Atta sexdens (1) affects approximately $20 \%$ of fruiting Protium heptaphyllum (Aubl.) March. trees and their seed crops; (2) promotes short-distance seed dispersal and high levels of seed aggregation; and (3) reduces seedling survival beneath parents. While $13.5 \%$ of the seeds from samples of untouched seeds became seedlings and survived a period of 13 months, it reached only $1.5 \%$ of the seeds piled by LCAs because mean seedling mortality was significantly higher in ant-made seed piles during this period. Thus, ants appear to magnify any negative impact of natural short-distance seed dispersal in P. heptaphyllum since seedlings from untouched seed samples also faced high levels of mortality beneath parent trees.

In this study, the elevated rate of seedling mortality was partially due to the intense cutting of seedlings regularly executed by ants around the gallery entrances and parallel to seedling recruitment. Four aspects of this whole process have been poorly described in the literature and differ from regular foraging behaviours in Atta, including other populations of A. sexdens: (1) ant 
foraging via subterraneous galleries targeted to the seed sources; (2) massive seed disposal around gallery entrances subsequent to the aril removal inside the galleries; (3) short-distance seed dispersal around parental trees; and (4) regular and massive seedling cutting in seedling clumps around gallery entrances. Atta species usually (1) forage on seeds via aboveground trails (Farji-Brener \& Silva 1996, Dalling \& Wirth 1998); (2) carry seeds to nests far away from parental plants and lose significant numbers of them during the transport along the extended foraging trails (Lugo et al. 1973, Leal \& Oliveira 1998, Wirth et al. 2003); and (3) discard seeds in subterraneous or external refuse dumps (Peternelli et al. 2003, Farji-Brener $\&$ Medina 2000). Our findings represent new aspects of seed foraging in LCAs and extend our understanding about plasticity and opportunistic foraging of LCAs as highlighted by Rockwood and Hubbell (1987), and Kost et al. (2005).

Removal of foliar vegetation in the vicinity and above the nest has been recorded for many LCAs species (Farji-Brener \& Illes 2000, Hull-Sanders \& Howard 2003). This so called 'nest clearing' behaviour is associated to construction, expansion and maintenance of nests, and it is so drastic that it promotes vegetation-free zones of 50-160 $\mathrm{m}^{2}$ in the forest understory (Garrettson et al. 1998, Farji-Brener \& Illes 2000). Here we found a similar ant activity, but targeted at the vegetation around the entrance of subterraneous galleries leading to $P$. heptaphyllum trees. The result is that seed dispersal by LCA species, characterized by seed piling at gallery entrances, is expected to drive $100 \%$ of the seedlings on seed piles to death while colonies are active (10-20 yr, Weber 1972). This may overcome any positive benefit plants would have from seed manipulation by ants.

There are four ways through which aboveground foraging by LCAs can provide seed dispersal services and positively contribute to seedling recruitment of primarily vertebrate-dispersed species: (1) by seed cleaning (Oliveira et al. 1995, Leal \& Oliveira 1998, Peternelli et al. 2003); (2) by accidentally loosing seeds/ fruits along foraging trails (Leal \& Oliveira 1998); (3) by secondary disposal of seeds on external refuse dumps and/or the nest surface, the soils of which contain higher levels of nutrients and humidity and thus favour seed germination and seedling performance (Farji-Brener \& Medina 2000, Varela \& Perera 2003, Farji-Brener \& Ghermandi 2004); and (4) by secondary disposal of seeds on external refuse dumps (e.g., Atta colombica, Acromyrmex lobicornis) in which seeds are postdispersed either by litter ants (Leal \& Oliveira 1998) or passively by heavy rains which were observed to spread out the refuse (Dalling \& Wirth 1998). The crucial difference of aboveground foraging, as opposed to gallery foraging, is that gallery-based foraging, by promoting seed aggregation beneath parent trees, reduces the probability of long distance dispersal by ants (i.e., by accidentally loosing seeds up to $200 \mathrm{~m}$ along foraging trails) and thereby allows for regular seedling cutting by ants during a long post-recruitment period.

In synthesis, because LCAs are generalist herbivores that opportunistically exploit a broad array of plant resources, their ultimate impact on plant recruitment depends on species specific harvesting modes and the given environmental situation. In some situations, they provide beneficial seed dispersal services for plant species, what has been described as a non-specialized mutualism (Varela \& Perera 2003). In other situations or simultaneously, LCAs rather operate as seed wasters and seedling predators. In the present case for instance, A. sexdens did not affect seed germination but promoted reduced seedling survival beneath parents by accessing both seeds and seedlings by long-lasting subterraneous foraging galleries. This may have negative effects for the reproductive success of $P$. heptaphyllum trees. Consequently, we must extend our knowledge about variables promoting both intra- and interspecific differences in LCA behaviour in order to provide more accurate generalizations about the role played by these ants on seed dispersal of non-myrmecochorous plants.

Acknowledgments - We thank the "Conselho Nacional de Desenvolvimento Científico e Tecnológico" (CNPq), and "Conservação Internacional do Brasil" for funding this study. We also thank J.W. Dalling, and H. Vasconcelos for helpful comments on early versions of this manuscript. Two anonymous referees provided useful criticism on the manuscript.

\section{References}

CHERRETT, J.M. 1989. Leaf-cutting ants, biogeographical and ecological studies. In Ecosystem of the world 14B (H. Lieth \& M.J.A. Werger, eds.). Elsevier, New York, p.473-488.

DALLING, J.W. \& WIRTH, R. 1998. Dispersal of Miconia argentea seeds by the leaf-cutting ant Atta colombica. Journal of Tropical Ecology 14:705-710.

FARJI-BRENER, A.G. \& GHERMANDI, L. 2004. Seedling recruitment in a semi-arid Patagonian steppe: facilitative effects of refuse dumps of leaf-cutting ants. Journal of Vegetation Science 15:823-830.

FARJI-BRENER, A.G. \& ILLES, A.E. 2000. Do leaf-cutting ant nest make bottom-up gaps in neotropical rain forests? A critical review of evidence. Ecology Letters 3:215-227. 
FARJI-BRENER, A.G. \& MEDINA, C. 2000. The importance of where to dump the refuse: seed banks and fine roots in the nest of the leaf-cutting ants Atta cephalotes and Atta colombica. Biotropica 32:120-126.

FARJI-BRENER, A.G. \&. SILVA, J.F. 1996. 'Leaf-cutter ants' (Atta laevigata) aid the establishment success of Tapirira velutinifolia (Anacardiaceae) seedlings in a parkland savanna. Journal of Tropical Ecology 12:163168.

FOWLER, H.G. \& CLAVER, S. 1991. Leaf-cutter ant assemblies: effects of latitude, vegetation, and behaviour. In Antplant interactions (C.R. Huxley \& D.F. Cutler, eds.). Oxford University Press, Oxford, p.51-59.

GARRETTSON, M., STETZEL, J.F., HALPERN, B.S., HEARN, D.J., LUCEY, B.T. \& MCKONE, M.J. 1998. Diversity and abundance of understorey plants on active and abandoned nest of leaf-cutting ants (Atta cephalotes) in Costa Rican rain forest. Journal of Tropical Ecology 14:17-26.

GUEDES, M.L.S. 1992. Estudo florístico e fitossociológico de um trecho da Reserva Ecológica da Mata de Dois Irmãos, Recife-Pernambuco. M.Sc. thesis. Universidade Federal Rural de Pernambuco, Recife.

HOWE, H.F. 1990. Seed dispersal by birds and mammals: implications for seedling demography. In Reproductive ecology of tropical forest plants (K.S. Bawa \& M. Hadley, eds.). UNESCO and The Parthenon Publishing Group, Paris, p.191-218.

HOWE, H.F. \& SMALLWOOD. J. 1982. Ecology of seed dispersal. Annual Review of Ecology and Systematics 13:201-228.

HULL-SANDERS, H.M. \& HOWARD, J.J. 2003. Impact of Atta colombica colonies on understory vegetation and light availability in a Neotropical forest. Biotropica 35:441-445.

KOST, C., GAMA DE OLIVEIRA, E., KNOCH, T. \& WIRTH, R. 2005. Spatio-temporal permanence and plasticity of foraging trails in young and mature leaf-cutting ant colonies (Atta spp.). Journal of Tropical Ecology 21:677688.

KREBS, C.J. 1999. Ecological methodology. Addison Wesley Longmann Inc. New York.

LEAL, I.R. \& OLIVEIRA, P.S. 1998. Interactions between fungus-growing ants (Attini), fruits and seeds in Cerrado vegetation in Southeast Brazil. Biotropica 30: 170-178.

LEIGH JUNIOR, E.G., WRIGHT, S.J. \&. HERRE, E.A. 1993. The decline of tree diversity on newly isolated tropical islands: a test of a null hypothesis and some implications. Evolution Ecology 7:76-102.

LEVEY, D.G., MOERMOND, T.C. \& DENSLOW, J. 1994. Frugivory: an overview. I $n$ La Selva: ecology and natural history of a neotropical rain forest (L.A. McDade, K.S. Bawa, H.A. Hespenheide \& G.S. Hartshorn, eds.). The University of Chicago Press, Chicago, p.282-294.
LUGO, A.E., FARNWORTH, E.G., POOL, G., JEREZ, P. \& KAUFMANN, G. 1973. The impact of the leaf-cutter ant Atta colombica on the energy flow of a tropical wet forest. Ecology 54:1292-1301.

MACHADO, I.C., LOPES, A.V.F. \& PÔRTO, K.C. 1998. Reserva Ecológica de Dois Irmãos: estudos em um remanescente de Mata Atlântica em área urbana (Recife - Pernambuco - Brasil). Editora da Universidade Federal de Pernambuco, Recife.

MOUTINHO, P., NEPSTAD, D.C., ARAÚJO, K. \& UHL, C. 1993. Formigas e floresta: estudo para a recuperação de áreas de pastagem. Ciência Hoje 15:59-60.

MOUTINHO, P., NEPSTAD, D.C. \& DAVIDSON, E.A. 2003. Influence of leaf-cutting ant nests on secondary forest growth and soil properties in Amazonia. Ecology 84: 1265-1276.

NASCIMENTO, M.T. \& PROCTOR, J. 1996. Seed attack by beetles and leaf-cutter ants on Peltogyne gracilipes Ducke (Caesalpiniaceae) on Maracá Island, Brazilian Amazonia. Journal of Tropical Ecology 12:723-727.

NEPSTAD, D., UHL, C. \& SERRÃO, E. 1990. Surmounting barriers to forest regeneration in abandoned highly degraded pastures: a case study from Paragominas, Para, Brazil. In Alternatives to deforestation: steps towards sustainable use of the Amazon rain forest (A. Anderson, ed.). Columbia University Press, New York, p. 215-229.

OLIVEIRA, P.S., GALETTI, M., PEDRONI, F. \& MORELLATO, L.P.C. 1995. Seed cleaning by Mycocepurus goeldii ants (Attini) facilitates germination in Hymenaea courbaril (Caesalpiniaceae). Biotropica 27:518-522.

PERES, C.A. \& ROOSMALEN, M.G.M. VAN. 2002. Patterns of primate frugivory in Amazonia and the Guianan shield: implications to the demography of large-seeded plants in overhunted forests. In Frugivory and seed dispersal: ecological, evolutionary and conservation issues (D. Levey, M. Galetti \& W. Silva, eds.). CABI Publishing, Oxford, p.407-423.

PETERNELLI, E.F.O., DELLALUCIA, T.M.C., PETERNELLI, L.A., MARTINS, S.V. \& BORGES, E.E.D.E. 2003. The interaction among workers of the genera Atta and Acromyrmex (Hymenoptera: Formicidae) and seeds of Mabea fistulifera (Euphorbiaceae), a pioneer tree species in Brazil. Sociobiology 42:597-603.

PIZO, M.A. \& OLIVEIRA, P.S. 1998. Interaction between ants and seeds of a nonmyrmecochorous neotropical tree, Cabralea canjerana (Meliaceae), in the Atlantic forest of Southeast Brazil. American Journal of Botany 85:669674.

RIBEIRO, L.F. \& TABARELLI, M. 2002. A structural gradient in cerrado vegetation of Brazil: changes in woody plant density, species richness, life history and plant composition. Journal of Tropical Ecology 18:775-794.

ROCKWOOD, L. L. \& HUBBELL, S.P. 1987. Host plant selection, diet, diversity, and optimal foraging in a tropical leaf-cutting ant. Oecologia 74:55-61. 
SHEPHERD, J.D. 1985. Adjusting foraging effort to resources in adjacent colonies of the leaf-cutting ant, Atta colombica. Biotropica 17:245-252.

SILVA, P.D. 2003. Dispersão de sementes de Protium heptaphyllum (Burseraceae) por Atta sexdens Linnaeus (Myrmicinae, Attini) em fragmento de floresta Atlântica brasileira. Tese de Mestrado. Universidade Federal de Pernambuco, Recife.

SOKAL, R.R. \& ROHLF, F.J. 1995. Biometry. W.H. Freeman and Company, New York.

SPIRONELLO, W. 1999. The Sapotaceae community ecology in a Central Amazonian forest: effects of seed dispersal and seed predation. Ph.D. thesis. University of Cambridge, UK.

TERBORGH, J. 1990. Seed and fruit dispersal - commentary. In Reproductive ecology of tropical forest plants (K.S. Bawa \& M. Hadley, eds.). UNESCO and The Parthenon Publishing Group, Paris, p.181-190.

TURNER, I.M. 2001. The ecology of trees in the tropical rain forest. Cambridge University Press.

VAN ROOSMALEN, M.G.M. 1985. Fruits of the Guianan flora. Institute of Systematic Botany, Netherlands.
VARELA, R.O. \& PERERA, T.C. 2003. Dispersal of Schinus fasciculatus seeds by the leaf-cutting ant Acromyrmex striatus in a shrubland of the dry Chaco, Argentina. Journal of Tropical Ecology 19:91-94.

VASCONCELOS, H.L. 1990. Foraging activity of two species of leaf-cutting ants (Atta) in a primary forest of the Central Amazon. Insectes Sociaux 37:131-145.

VELOSO, H.P., RANGEL-FILHO, A.L.R \& LIMA, J.C.A. 1991. Classificação da vegetação brasileira adaptada a um sistema universal. IBGE, Rio de Janeiro.

WEBER, N.A. 1972. Gardening ants: the Attines. The American Philosophical Society, Philadelphia.

WETTERER, J.K. 1991. Foraging ecology of the leaf-cutting ant Acromyrmex octospinosus in a Costa Rican rain forest. Psyche 98:361-371.

WILKINSON, L. 1996. SYSTAT, version 6.0. SPSS, Chicago, Illinois, USA.

WIRTH, R., BEYSCHLAG, W., RYEL, R., HERZ, H. \& HÖLLDOBLER, B. 2003. The herbivory of leaf-cutting ants: a case study on Atta colombica in the tropical rainforest of Panama. Ecological Studies 164, Springer Verlag, Berlin. 